\title{
PENDAPATAN ASLI DAERAH BERDAMPAK PADA KEMANDIRIAN KEUANGAN DAERAH
}

\author{
Rosmiaty Tarmizi
}

\begin{abstract}
Demands for reform in all fields are supported by all Indonesian people in addressing regional issues have an impact on the financial relationship between the Central Government and Local Government. Autonomy and financial balance is fair, proportionate and transparent to be one of the demands of regional and community.

The main characteristic of a region capable of autonomous autonomy lies in the financial ability to fund the implementation of local government with a degree of dependence on government is getting smaller. It is expected that the revenue (PAD) should be the biggest part in mobilizing funds local governance. Based on the above reasoning this study aims to look at local financial independence through a proportion of local revenues to total local revenue and ability to fund research activities.

The method used is descriptive qualitative analysis method by analyzing the ratio to measure the level of independence local finance Bandar Lampung municipality. The results showed that the level of financial independence Bandar Lampung municipality area is still low, it is seen from the ratio of revenue to total revenue is only $8.06 \%$, compared to operating expenses to be incurred only $9.83 \%$, which can be financed from local revenues while the remaining comes to tax natural resources as well as transfers from the central government and the provinces. Keywords: PAD, TPD, \& TBO (Pendapatan Asli Daerah, Total Pendapatan Daerah dan Total Belanja Opersional)
\end{abstract}

\section{LATAR BELAKANG}

Reformasi yang dimulai beberapa tahun terakhir ini telah merambah keseluruh aspek kehidupan. Salah satu aspek Reformasi yang dominan adalah aspek Pemerintahan. Aspek Pemerintahan yang dimaksud disini adalah aspek hubungan pemerintah pusat dengan daerah. Pada aspek ini isu yang mencuat adalah adanya tuntutan otonomi yang lebih luas dan nyata yang harus diberikan kepada pemerintah daerah khususnya pemerintah Kabupaten/Kota.

Otonomi daerah yang sedang bergulir saat ini telah dituangkan dalam UU No.22/1999 yang direvisi dengan undang-undang No.32 tahun 2004 tentang Perintahan Daerah ter=ntang perluasan wewenang Pemerintah Daerah. Di samping itu juga dengan diberlakukannya Undang-Undang No.25/ 1999 kemudian direvisi dengan Undang-Undang No.33 tahun 2004 tentang perimbangan keuangan antara pusat dan daerah, memberi keleluasaan bagi daerah untuk melaksanakan pemabangunan.

Dalam rangka melaksanakan otonomi daerah yang nyata dan bertanggungjaawab, sektor pendapatan asli daerah memegang peranan yang sangat penting, karena melalui sektor ini dapat dilihat sejauhmana suatu daerah dapat membiayai kegiatan pemerintahan dan pembangunan yang menjadi urusan rumah tangganya dan berapa besar ketergantungan daerah dari sumber Ekstern. Semakin kecil ketergantungan daerah dari sumber ekstern, bearti 
semakin tinggi kemandirian keuangan daerah dalam membiayai kegiatan pemerintahan dan pembangunan. Disamping itu efektivitas dan efisiensi realisasi penerimaan pendapatan asli daerah merupakan salah satu tolak ukur untuk menilai kinerja pemerintah daerah dalam mencapai kemandiriaan keuangan daerah.

Dalam penelitian ini data yang digunakan untuk menganalisa pendapatan asli daerah dalam kaitannya dengan kemandiriaan keuangan daerah adalah data APBD dari kodya Bandar Lampung untuk tahun anggaran 2007. Data APBD yang diperlukan untuk dasar analisa disajikan pada tabel 1.

\section{Tabel 1 \\ Anggaran dan Realisasi APBD \\ Kodya Bandar Lampung \\ Tahun Anggaran 2007 \\ (dalam ribuan rupiah)}

\begin{tabular}{|c|l|l|l|}
\hline No & \multicolumn{1}{|c|}{ Uraian } & \multicolumn{1}{|c|}{ Anggaran } & \multicolumn{1}{c|}{ Realisasi } \\
\hline I & PENDAPATAN DAERAH & & \\
\hline & Pendapatan Asli Daerah & $54.629 .930,061$ & $53.714 .914,761$ \\
\hline & $\begin{array}{l}\text { Bagi Hasil Pajak \& Bagi Hasil Sumber Daya } \\
\text { Alam dari Pemerintah Pusat }\end{array}$ & $43.970 .000,00$ & $53.232 .603,696$ \\
\hline & Dana Bagi Hasil Pajak dari Provinsi & $21.575 .000,00$ & $30.052 .791,222$ \\
\hline & Pendapatan Lainnya & $526.771 .617,284$ & $528.972 .838,483$ \\
\hline & & & \\
\hline & Total Pendapatan Daerah & $\mathbf{6 4 6 . 9 4 9 . 5 4 7 , 3 4 5}$ & $\mathbf{6 6 5 . 9 7 3 . 2 0 8 , 1 6 2}$ \\
\hline II & BELANJA & & \\
\hline & Belanja Operasi & $557.593 .804,530$ & $546.565 .703,807$ \\
\hline & Belanja Lainnya & & \\
\hline & Total Belanja & $\mathbf{7 0 1 . 4 6 2 . 0 9 4 , 8 0 3}$ & $\mathbf{6 6 0 . 0 7 5 . 2 6 3 , 3 4 8}$ \\
\hline & Surplus (defisit) & $\mathbf{( 5 4 . 5 1 5 . 5 4 7 , 4 5 7 )}$ & $5.897 .944,824$ \\
\hline & Pembiayaan & $54.515 .547,457$ & $57.887 .417,378$ \\
\hline & & $\mathbf{0}$ & \\
\hline & Sisa Lebih Pembiayaan Anggaran & & $\mathbf{6 3 . 7 8 5 . 3 6 2 , 5 2}$ \\
& & & \\
\hline
\end{tabular}

Sumber: Laporan realisasi anggaran Kodya Bandar Lampung Tahun 2007, data diolah

\section{TINJAUAN PUSTAKA}

\subsection{Otonomi Daerah}

Dengan adanya reformasi dibidang Pemerintahan maka UU NO.5/1974 diganti dengan UU No.22/1999 yang direvisi dengan UU No.32 tahun 2004 tentang perlunya dilaksanakan otonomi daerah dan UU No.25 yang direvisi dengan UU No.34 tahun 2004 tentang Keuangan Daerah. Kedua undang-undang ini memberi kewenangan bagi daerah otonom untuk mengatur dan mengurus masyarakatnya menurut kehendak sendiri berdasarkan aspirasi masyarakat sesuai dengan perundang-undangan yang berlaku.

Tujuan otonomi daerah menurut UU No.22/1999 adalah untuk memacu pemerataan pembangunan dan hasil-hasilnya, meningkatkan kesejahteraan rakyat, menggalakkan prakasa dan peran serta aktif masyarakat serta peningkatan pendayagunaan potensi daerah secara optimal dan terpadu secara nyata, dinamis dan bertanggungjawab sehingga memperkuat 
persatuan dan kesatuan bangsa, mengurangi beban dan campur tangan pemerintah pusat di daerah yang akan memberikan peluang untuk koordinasi tingkat lokal.

Pencapaian tujuan otonomi daerah ini tentunya tergantung dari kesiapan masingmasing daerah dan kemampuan daerah dalam menggali potensi daerah untuk membiayai jalannya pemerintahan dan pembangunan daerah termasuk efektivitas dan efisiensi pengelolaan keuangan daerah.

\section{Sumber-Sumber Pendapatan Asli Daerah}

Pendapatan asli daerah merupakan semua penerimaan daerah yang berasal dari sumber ekonomi asli daerah. Berdasarkan UU No.25 tahun 1999 Sumer-sumber pendapatan asli daerah meliputi Pajak Daerah, Retribusi Daerah, Pendapatan Hasil Kekayaan Daerah yang dipisahkan dan lain-lain pendapatan yang sah.

\section{Kemandirian Keuangan Daerah}

Untuk melihat kemampuan daerah dalam menjalankan otonomi daerah salah satunya bisa diukur melalui ratio-ratio keuangan daerah dalam rangka kemandirian keuangan daerah. Yang terdiri dari:

1. Ratio Pendapatan Asli Daerah (PAD) terhadap Total Penerimaan Daerah (TPD) dengan menggunakan rumus berikut:

$$
\text { Ratio PAD terhadap TPD }=\frac{P A D}{T P D} \times 100 \%
$$

Ratio ini menggambarkan kontribusi pendapatan asli daerah terhadap total penerimaan, semakin besar ratio kontribusi bearti semakin besar pula kemandiriaann keuangan daerah.

2. Ratio Bagi Hasil Pajak dan Bukan Pajak (BHP/BHBP) terhadap Total Penerimaan Daerah (TPD) dengan menggunakan rumus :

$$
\begin{gathered}
\text { Ratio } B H P / B H B P \text { terhadap TPD }= \\
\frac{\mathrm{BHP} / \mathrm{BHBP}}{T P D} \times 100 \%
\end{gathered}
$$

Ratio ini menggambarkan kontribusi bagi hasil pajak dan bukan pajak. Ratio ini berbanding searah dengan tingkat kemandirian keuangan daerah artinya semakin tinggi ratio BHP/BHBP semakin tinggi pula tingkat kemandirian keuangan daerah.

3. Ratio Pendapatan Asli Daerah (PAD) terhadap Total Belanja Operasi (TBO) dengan menggunkan rumus berikut:

$$
\text { Ratio PAD terhadap TBO }=\frac{P A D}{T B O} \times 100 \%
$$

Ratio ini menggambarkan kemampuan daerah untuk membiayai belanja operasi yang berasal dari sumber intern pemerintah daerah. Ratio ini juga berbanding searah dengan tingkat kemandirian keuangan daerah.

4. Ratio Pendapatan Asli Daerah (PAD) ditambah dengan Bagi Hasil Pajak dan Bukan Pajak (BHP/BHBP) terhadap Total Belanja Operasi (TBO) dengan menggunakan rumus:

$$
=\frac{\text { Ratio PAD }+ \text { BHP } / \text { BHBP }=}{\text { Terhadap TBO }}=
$$


Ratio ini menggambarkan kemampuan daerah dari hasil yang diperoleh daerah dalam membiayai belanja operasi rasio ini berbanding searah dengan kemandirian keuangan daerah.

5. Ratio efektivitas dan ratio efisiensi digunakan untuk mengukur kinerja pemerintah daerah dalam merealisasikan peneriman pendapatan asli daerah dengan menggunakan rumus sebagai berikut:

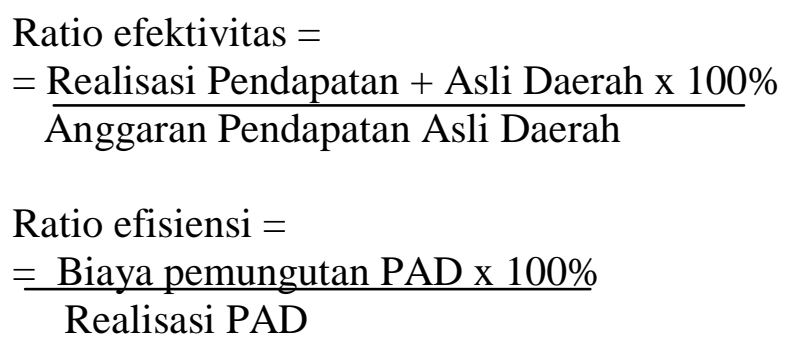

Ratio ini menunjukkan semakin tinggi ratio efektivitas dan ratio efisiensi terhadap realisasi penerimaan PAD berarti kinerja pemerintah semakin baik. ( Abdul Halim, 2007, hal. 232).

\section{PEMBAHASAN}

Untuk melihat kemandirian keuangan pemerintah daerah perlu dilakukan penilaian mengenai proporsi pendapatan asli daerah terhadap total penerimaan daerah dan kontribusi pendapatan asli daerah dalam membiayai pengeluaran rutin. Di samping itu juga akan dinilai bagaimana kinerja pemerintah daerah dalam merealisir penerimaan pendapatan asli daerah yang telah ditargetkan.

\section{Analisis Kemandirian Keuangan Daerah}

Alat analisis ini digunakan untuk mengukur tingkat kemandirian pemerintah daerah dengan menggunakan 4 indikator, yaitu proporsi pendapatan asli daerah terhadap total penerimaan daerah. Proporsi bagi hasil pajak dan bukan pajak terhadap total penerimaan daerah, kontribusi pendapatan asli daerah dalam membiayai pengeluaran rutin dan kontribusi pendapatan asli daerah ditambah bagi hasil pajak dan bukan pajak dalam membiayai pengeluaran rutin.

Berdasarkan data pada tabel 1 dapat dihitung 4 indikator di atas.

Ratio Pendapatan Asli Daerah

Terhadap Total Penerimaan $=$

$=\underline{53.714 .914,761 \times 100 \%}$

$665.973 .208,162$

$=8,06 \%$

Ratio Bagi Hasil Pajak Dan Bukan Pajak

Terhadap Total Penerimaan $=$

83.285.454,918

$665.973 .208,162$

$\mathrm{x} 100 \%=12,51 \%$ 
Ratio Pendapatan Asli Daerah

Terhadap Total Belanja Operasi $=$

$53.714 .914,761$

$546.565 .703,807$

Ratio Pendapatan Asli Daerah+Bagi hasil pajak dan bukan pajak Terhadap Hasl Total Belanja Operasi $=$ 83.285.454,918

$546.565 .703,807$

Dari hasil penelitian di atas dapat dilihat bahwa proporsi pendapatan asli daerah terhadap total penerimaan sangat kecil sekali, yaitu hanya $8,06 \%$, begitu juga proporsi bagi hasil pajak dan bukan pajak hanya $12,51 \%$. Ini menunjukkan bahwa penerimaan pendapatan daerah masih didominasi oleh sumbangan dan bantuan dari pemerintah pusat dan provinsi. Begitu juga halnya dengan pembiayaan belanja rutin menunjukkan tingkat ketergantungan daerah kodya Bandar Lampung masih cukup besar pada pemerintah pusat dan provinsi. Hanya 25,06\% yang dapat dibiayai oleh pendapatan asli daerah ditambah bagi hasil pajak dan bukan pajak. Kondisi ini menggambarkan bahwa tingkat kemandirian keuangan masih sangat rendah.

\section{Analisis Efektivitas dan Efisiensi}

Alat analisis ini digunakan untuk mengukur kemampuan pemerintah daerah dalam merealisir penerimaan pendapatan asli daerah. Untuk itu digunakan indikator yaitu perbandingan antara realisasi PAD dengan anggaran yang ditetapkan dan perbandingan antara biaya yang dikeluarkan untuk memungut pendapatan asli daerah dengan realisasi penerimaan pendapatan asli daerah.

Biaya pemungutan pendapatan asli daerah untuk tahun anggaran 2007 adalah sebesar Rp 9.603.941,704 dengan demikian dapat dihitung ratio dan efektivitas dan efisiensi sebagai berikut:

Ratio efektivitas $=$

$53.714 .914,761$

$\longrightarrow 100 \%=98,32 \%$

$54.629 .430,061$

Ratio efisiensi $=$

9.603.941,704

$53.714 .914,761$

Dari hasil perhitungan di atas diketahui bahwa ratio efektivitas pemerintah dalam melakukan pemungutan pendapatan asli daerah mencapai $98,32 \%$ dan ratio efisiensi sebesar $17,88 \%$. Hal ini menggambarkan kinerja pemerintah daerah dalam merealisir pendapatan asli daerah masih belum cukup baik karena dari anggaran yang ditetapkan belum semuanya dapat terealisir. Walaupun demikian dari segi efisiensi pengelolaan sudah cukup efisien. 


\section{KESIMPULAN DAN SARAN}

\subsection{Kesimpulan}

Keberhasilan otonomi daerah memerlukan kemandirian keuangan bagi masingmasing daerah otonomi khususnya dalam membiayai pengeluaran rutin, sehingga bantuan dan sumbangan pemerintah pusat/provinsi dapat digunakan untuk meningkatkan pembangunan.

Berdasarkan hasil analisis sebelumnya dapat disimpulkan hal-hal sebagai berikut:

1) Kemandirian daerah Kodya Bandar Lampung pada anggaran 2007 masih rendah. Hal ini dapat dilihat dari sangat rendahnya proporsi bagi hasil pajak dan bukan pajak terhadap total penerimaan daerah. Untuk ratio proporsi pendapatan asli daerah hanya 8,06\% data ratio proporsi bagi hasil pajak dan bukan pajak hanya $12,51 \%$. Hal ini berarti bahwa kontribusi pemerintah pusat/provinsi masih cukup besar, yaitu $\pm 87,09 \%$ dari total penerimaan daerah.

2) Jika dilihat dari kemampuan pendapatan asli daerah dalam mendanai belanja rutin juga rendah, yaitu hanya 9,83\% dan dengan ditambah bagi hasil pajak dan bukan pajak rationya menjadi $25,06 \%$. Hal ini juga berindikasi dalam pembiayaan rutin pun masih memerlukan bantuan dari pemerintah pusat/provinsi.

3) Dilihat dari kinerja pemerintah daerah dalam merealisir penerimaan pendapatan asli daerah belum cukup baik ditinjau dari ratio efektivitas walaupun dari segi efisiensi sudah cukup efisien.

\subsection{Saran}

Dari kesimpulan dapat dilihat bahwa kemandirian keuangan pemeritah daerah masih kurang meskipun kinerja untuk merealisir sudah baik. Untuk itu perlu diupayakan untuk menggali sumber-sumber pendapatan asli daerah dengan memperhatikan alokasi faktor produksi dan keadilan.

\section{DAFTAR PUSTAKA}

Abdul Halim, Akt 2007, Akuntansi Keuangan Daerah Penerbit Salemba Empat, Jakarta.

Abdul Halim, 2002, Manajemen Keuangan Daerah Bunga Rampai Penerbit UPP AMP YKPN, Yogyakarta.

Kirana Raya, Wihana Model Analisis Potensi Keuangan Daerah: Kerja Sama Ditjen PUOD Depdagri dan Pusat Penelitan dan Pengkajian Ekonomi dan Bisnis, Universitas Gajah Mada, Yogyakarta.

Widodo, 2001. Analisis Rasio Keuangan pada APBD Kabupaten Boyolali, Bunga Rampai Manajemen Keuangan Daerah.

Yulianti, 2001. Analisis Kemampuan Keuangan Daerah dalam Menghadapi Otonomi Daerah, Bunga Rampai Manajemen Keuangan Daerah.

, Undang-Undang No. 22 tahun 1999 Tentang Panduan Daerah dan UndangUndang No.25 tahun 1999 tentang Perimbangan-Keuangan antara Pemerintah Pusat dan Daerah. 